\title{
Antioxidant, anti-inflammatory, and anti-Staphylococcal activities of Albizia lucidior (Steud.) I. C. Nielsen wood extracts
}

Pathompong Phuaklee ${ }^{\mathrm{a}, *}$, Bhanuz Dechayont ${ }^{\mathrm{a}}$, Jitpisute Chunthorng-Orn ${ }^{\mathrm{a}}$, Onmanee Prajuabjinda ${ }^{\mathrm{a}}$, Thana Juckmeta $^{\mathrm{b}}$, Kitrawee Jiraratsatit ${ }^{\mathrm{c}}$, Kanmanee Sukkasem ${ }^{\mathrm{a}}$, Khwanchanok Mokmued ${ }^{\mathrm{d}}$, Kitiya Yangthaworn ${ }^{\mathrm{a}}$

a Department of Applied Thai Traditional Medicine, Faculty of Medicine, Thammasat University, Pathum Thani 12120 Thailand

b School of Medicine, Walailak University, Nakhon Si Thammarat 80160 Thailand

c Faculty of Public Health, Thammasat University, Pathum Thani 12120 Thailand

d Division of Applied Thai Traditional Medicine, Faculty of Public Health, Naresuan University, Phitsanulok 65000 Thailand

*Corresponding author, e-mail: thompong1986@gmail.com

Received $17 \mathrm{Feb} 2021$

Accepted 30 Jul 2021

ABSTRACT: Albizia lucidior (Steud.) I. C. Nielsen is a leguminous tropical hardwood tree that is of great interest as a herbal medicine. In this study, both ethanolic and aqueous extracts of A. lucidior wood were investigated. The phenolic and flavonoid contents of the extracts were measured, and the antioxidant and anti-inflammatory activities were evaluated by inhibition of tumor necrosis factor $\alpha$ and nitric oxide production. Cytotoxic activity against macrophages was determined by the MTT assay, and antimicrobial activities were tested against Staphylococcus aureus, methicillin resistant Staphylococcus aureus (MRSA), and Staphylococcus epidermidis, measuring the minimum inhibitory and bactericidal concentrations. The chemical composition of the extracts was analyzed by GC-MS. The aqueous extract had higher total phenolic content than the ethanolic extract. Both extracts had strong antioxidant activity in the DPPH assay, with respective $\mathrm{IC}_{50}$ values of 7.12 and $9.02 \mu \mathrm{g} / \mathrm{ml}$. In the ABTS assay, the aqueous extract had a lower $\mathrm{IC}_{50}(9.50 \mu \mathrm{g} / \mathrm{ml})$ than the ethanolic extract. The ethanolic extract significantly inhibited NO, but the aqueous extract showed no inhibitory activity. However, neither extract significantly inhibited TNF- $\alpha$ production. Significant antibacterial activity was found only in the ethanolic extract with an MIC and an MBC against $S$. aureus of $2.5 \mathrm{mg} / \mathrm{ml}$ and $5.0 \mathrm{mg} / \mathrm{ml}$, respectively. From our knowledge, this is the first study of the antioxidant, anti-inflammatory, and anti-Staphylococcal activities of A. lucidior wood extracts. The significant anti-Staphylococcal activity should be further explored in preclinical studies.

KEYWORDS: Albizia lucidior, antioxidant, anti-inflammatory, anti-Staphylococcal activity, phenolic content, flavonoid

\section{INTRODUCTION}

Pyrexia, or fever, is an adaptive response of the body to infection (e.g., exogenous bacterial pyrogens), malignancy, or other disease states [1]. The body uses this natural function in trying to create an environment in which infectious agents or damaged tissues cannot survive. Infected or damaged tissues normally induce the formation of proinflammatory mediators, called cytokines, such as interleukins $(-1 \beta,-\alpha$, and $-\beta)$ and tumor necrosis factor $\alpha$, all of which increase the synthesis of prostaglandin E2 (PGE2) in the hypothalamus causing an elevation of body temperature [2].

Conventional drugs for treatment of fever and pain like nonsteroidal anti-inflammatory drugs (NSAIDs) may be associated with clinically significant side effects affecting the digestive system, kidneys, liver, central nervous system, or skin [3]. An alternative for the treatment could be herbal medicines, which also tend to have a broader range of applications, e.g., a single herbal medicine may exert anti-inflammatory, antioxidant, and antibacterial activities.

The antioxidant activity of natural substances is an area of great interest because some of them can preserve foods and protect them from the toxic effects of oxidation [4]. Besides, natural agents with free radical scavenging ability can play a significant role in the prevention or treatment of some diseases 
such as brain dysfunction, cancer, heart disease, gastrointestinal disease, and immune system decline $[5,6]$.

In herbal medicine, a single plant species is often used to treat more than one type of diseases or conditions. However, the scientific basis for such use may be unknown and should be investigated to ascertain any potential activity against human pathogens that could be exploited clinically.

Albizia lucidior is a species of leguminous tropical hardwood tree in the Fabaceae family. Its wood is commonly used as a traditional treatment for various ailments as an antipyretic, an appetite stimulant, and a tonic; whereas the bark and wood are used as laxatives and cathartics. However, a thorough literature search reveals very limited scientific data of its medicinal properties. The purpose of this study was to assess the antioxidant, antiinflammatory, and anti-Staphylococcal activities of A. lucidior.

\section{MATERIALS AND METHODS}

\section{Chemicals and reagents}

All reagents were of analytical grade. The following items were purchased from SigmaAldrich, USA: clarithromycin, dimethylsulfoxide (DMSO), lipopolysaccharide from E. coli O55:B5 (LPS), thiazolyl blue tetrazolium bromide (MTT), 2,2-diphenyl-1-picryhydrazyl (DPPH), 2,2'-Azinobis (3-ethylbenzothiazoline-6-sulfonic acid) diammonium salt, aluminium chloride, potassium acetate, gallic acid, butylated hydroxytoluene (BHT), and resazurin sodium salt. Folin-Ciocalteu's reagent was purchased from Fluka, USA. Mueller Hinton Broth (MHB) and Nutrient broth (NA) were procured from RPD, Thailand. Brain heart infusion (BHI) and anaeropack were obtained from Difco, USA. Roswell Park Memorial Institute (RPMI) 1640, fetal bovine serum (FBS), trypsin-EDTA, and trypan blue were purchased from Gibco BRL, USA.

\section{Plant materials}

Albizia lucidior wood was purchased from a herbal medicine shop in Nakhon Pathom, Thailand in January 2018. The wood's botanical identification was authenticated at the Department of Applied Thai Traditional Medicine, Faculty of Medicine, Thammasat University.

\section{Microorganisms}

Staphylococcus aureus ATCC 25923, methicillin resistant Staphylococcus aureus (MRSA) ATCC 20651, and Staphylococcus epidermidis ATCC 12228 were obtained from the culture collections of the Center of Excellence in Applied Thai Traditional Medicine, Faculty of Medicine, Thammasat University.

\section{Preparation of the extracts}

The wood was washed, dried, and ground before extraction. Two extracts, aqueous and ethanolic, were prepared according to Dechayont et al [7]. The aqueous extract was prepared by boiling the wood powder in water for $30 \mathrm{~min}$, followed by filtration using Whatman \#1 filter paper. The liquid was first frozen and then partially dried using a lyophilizer resulting in a viscous liquid. The ethanolic extract was prepared by soaking the wood powder in $95 \%$ $\mathrm{EtOH}$ for $72 \mathrm{~h}$, then filtered, and partially dried in an evaporator. The whole process was repeated three times to yield the viscous ethanolic extract. Both the aqueous and ethanolic extracts were kept at $-20^{\circ} \mathrm{C}$ before further uses.

\section{Total phenolic content}

Total phenolics were estimated as gallic acid equivalents (GAE), expressed as mg GAE/g. Briefly, $20 \mu \mathrm{l}$ of sample $(1000 \mu \mathrm{g} / \mathrm{ml})$ was added to 96 well plates followed by $100 \mu \mathrm{l}$ of Folin-Ciocalteu reagent (diluted 10-fold). After $3 \mathrm{~min}, 80 \mu \mathrm{l}$ of $7.5 \% \mathrm{w} / \mathrm{v}$ $\mathrm{Na}_{2} \mathrm{CO}_{3}$ was added, and the reaction mixture was allowed to stand for 30 min before the absorbance at $765 \mathrm{~nm}$ was measured [8].

\section{Total flavonoid content}

Total flavonoids were estimated as quercetin equivalents (QE), expressed as mg QE/g. Briefly, $20 \mu \mathrm{l}$ of sample $(1000 \mu \mathrm{g} / \mathrm{ml}), 60 \mu \mathrm{l}$ of methanol, $10 \mu \mathrm{l}$ of aluminium chloride $(10 \% \mathrm{w} / \mathrm{v}), 10 \mu \mathrm{l}$ of potassium acetate $(1 \mathrm{M})$, and $120 \mu \mathrm{l}$ of distilled water were mixed in 96 well plates. The mixture was incubated at room temperature for $30 \mathrm{~min}$. Then, absorbance was determined at $415 \mathrm{~nm}$ [8].

\section{Determination of antioxidant activities \\ DPPH radical scavenging assay}

DPPH radical scavenging activity was measured using a slightly modified method of Dechayont et al [9]. DPPH solution in absolute ethanol was newly prepared before use and protected from light. A $100 \mu \mathrm{l}$ portion of each sample solution or control was mixed with $100 \mu$ l of DPPH solution (in a 1:1 ratio) in 96-well plates, and the mixture was allowed to sit at room temperature for $30 \mathrm{~min}$, protected from light. BHT was used as a positive 
control. Absorbance was then measured at $520 \mathrm{~nm}$. The percent inhibition of DPPH free radical scavenging activity was calculated using the following equation:

$$
\% \text { Inhibition }=\left[\left(\mathrm{A}_{\mathrm{DPPH}}-\mathrm{A}_{\text {sample }}\right) / \mathrm{A}_{\mathrm{DPPH}}\right] \times 100
$$

where $\mathrm{A}_{\mathrm{DPPH}}=$ absorbance of DPPH and $\mathrm{A}_{\text {sample }}=$ absorbance of sample.

The percent inhibition data was plotted against the log concentration and fitted to a graph. The $\mathrm{IC}_{50}$ (half-maximal inhibitory concentration) value was calculated using Prism software.

\section{ABTS radical cation decolorization assay}

The ABTS radical cation decolorization assay was performed following the method of Re et al [10] with slight modification. The $\mathrm{ABTS}^{\bullet+}$ solution was produced by the reaction of $7 \mathrm{mM}$ ABTS stock solution in distilled water with $2.45 \mathrm{mM}$ potassium persulfate. A $20 \mu \mathrm{l}$ portion of each sample solution was combined with $180 \mu \mathrm{l}$ of the $\mathrm{ABTS}^{\bullet+}$ solution in 96-well plates, and the mixture was left to react in the dark for 6 minutes. Absorbance was measured at $734 \mathrm{~nm}$, and BHT was used as a positive control.

\section{Anti-inflammatory activity}

\section{Nitric oxide-inhibitory effect}

Mouse macrophage leukemia-like cells (RAW 264.7, ATCC TIB-71TM) were induced with lipopolysaccharide (LPS) to release inflammatory mediators, including nitric oxide and tumor necrosis factoralpha (TNF- $\alpha$ ). Griess reagent was used for determination of the nitrite, a stable end product of nitric oxide (NO) in the cell culture supernatants, and the TNF- $\alpha$ production was measured using a commercial kit (ImmunoTools, Germany) following the manufacturer's protocols. The inhibitory effect on NO production was evaluated using the method of Suthisamphat et al [11]. Approximately 100000 cells were seeded into each well of 96well plates along with Dulbecco's Modified Eagle Medium (DMEM) and incubated for $24 \mathrm{~h}$. The medium was then removed and replaced with fresh medium. LPS was added for a final concentration of $5 \mathrm{ng} / \mathrm{ml}$. The Albizia lucidior extracts of various concentrations were also added. After $24 \mathrm{~h}$ of further incubation, the ability of the extract to inhibit NO in the supernatant was detected by adding $100 \mu \mathrm{l}$ of Griess reagent and reading the absorbance at $570 \mathrm{~nm}$. The percent inhibition was calculated using the following equation:

$$
\% \text { Inhibition }=[(\mathrm{A}-\mathrm{C})-(\mathrm{B}-\mathrm{D})] /(\mathrm{A}-\mathrm{C}) \times 100
$$

where $\mathrm{A}=$ control, with no sample but in the presence of LPS; $B=$ sample, in the presence of LPS; $\mathrm{C}=$ blank of $\mathrm{A}$, in the absence of sample and LPS; and $\mathrm{D}=$ blank of $\mathrm{B}$, with sample but in the absence of LPS.

$\mathrm{IC}_{50}$ values were calculated from the percent inhibition of concentrations using the Prism program.

\section{TNF- $\alpha$ inhibitory effect in RAW 264.7 cells by ELISA}

RAW 264.7 cells were incubated with $5 \mathrm{ng} / \mathrm{ml}$ of LPS and the extract for $24 \mathrm{~h}$. Then TNF- $\alpha$ levels in the supernatants were determined using an ELISA kit (ImmunoTools) following the manufacturer's instructions [12].

\section{Cytotoxicity by MTT method}

Cell viability was determined using the MTT assay. Macrophage cells (RAW 264.7) were divided into two experimental groups: (1) the control group consisting of only added medium and (2) the sample group having added medium and the A. lucidior extracts in various concentrations. The two experimental groups were incubated in 96-well plates for $24 \mathrm{~h}$. A $10 \mu \mathrm{l}$ portion of MTT solution $(5 \mathrm{mg} / \mathrm{ml})$ was then added to each well, and incubation proceeded for another $4 \mathrm{~h}$ at $37^{\circ} \mathrm{C}$. Next, $100 \mu \mathrm{l}$ of dimethyl sulfoxide (DMSO) was added to each well to dissolve any deposited formazan. The optical density (OD) of each well was measured at $570 \mathrm{~nm}$ using a microplate reader. Percentage of cell survival was calculated using the equation:

$$
\% \text { Cell viability }=(\mathrm{Ae} / \mathrm{Ac}) \times 100
$$

where Ae and Ac are the absorbance of the extract and the control groups, respectively.

\section{Antimicrobial activity \\ Microorganism and culture conditions}

Staphylococcus aureus ATCC 25923, methicillin resistant Staphylococcus aureus (MRSA) ATCC 20651, and Staphylococcus epidermidis ATCC 12228 were used to determine the minimum inhibitory concentration (MIC) and minimum bactericidal concentration (MBC) of the A. lucidior extracts. Prior to each experiment, the cultures were incubated through three successive generations by letting them grow for three successive nights in nutrient agar (NA).

\section{Determination of minimum inhibitory concentration (MIC)}

The MICs of the A. lucidior extracts were determined in 96-well microplates plates using microdilution as- 
say, a slightly modified method of Sarker et al [13]. This technique relies on resazurin, an oxidationreduction indicator used for evaluating cell growth, particularly in the cytotoxic activity assay [14]. Broth cultures of $S$. aureus, MRSA, and S. epidermidis were prepared and then incubated for 18$24 \mathrm{~h}$, depending on the individual bacteria. When the cultures reached the required density of 0.5 McFarland Standard, each was diluted with broth at a ratio of 1:200. Two-fold serial dilutions of the wood extracts were prepared directly in sterile 96 well plates as follows. Each of the viscous extracts (aqueous and ethanolic) was diluted 1:1 with broth. All the 96 wells of the plate were filled with $50 \mu$ l of bacterial suspension. Then, $50 \mu \mathrm{l}$ of the diluted extract was added to the first row of the plate. After mixing, the $100 \mu \mathrm{l}$ of the first row contents were pipetted to the second row. This two-fold dilution procedure continued for a total of five rows. The plates were then incubated again for the same bacterium-specific times as before. Next, $10 \mu \mathrm{l}$ of resazurin was added to each well and incubated for an additional $2 \mathrm{~h}$. Color changes were assessed visually. The MIC was defined by the lowest concentration of the extract that did not result in a color change from purple to pink or no color. Measurements were made in triplicate, and the mean value was used.

\section{Minimum bactericidal concentration}

The MBCs were determined using the well plates from the end of the MIC assay. The contents of all the MIC assay wells with no visible growth were transferred to agar plates, incubated at $37^{\circ} \mathrm{C}$ for $24 \mathrm{~h}$, and then assessed for bacterial growth. The quadrant with the lowest concentration of wood extract that showed no growth was the MBC. The assay was done in triplicate, and the mean value was used. Extract concentrations were recorded as $\mathrm{mg} / \mathrm{ml}$.

\section{Statistical analysis}

All experiments were carried out in triplicate and presented as means \pm SEM (standard error of the mean).

\section{Gas chromatography-mass spectrometry (GC-MS) analysis}

The chemical composition of the wood ethanolic extract of A. lucidior was analyzed by the GC-MC technique using Bruker Scion 436-GC model coupled with a single quadruple mass spectrophotometer comprising of a CP-8410 autosampler. A fused silica capillary column, SCION-5MS (5\% phenyl/95\% dimethyl poly siloxane) $30 \mathrm{~m} \times 0.25 \mathrm{~mm} \times 0.25 \mu \mathrm{m}$, was run on helium gas with a flow rate of $1.2 \mathrm{ml} / \mathrm{min}$. The sample $(1 \mu \mathrm{l})$ was injected in the split ratio of 1:50 and run for $56 \mathrm{~min}$ throughout the experiment. The initial temperature of $80^{\circ} \mathrm{C}$ was gradually increased up to $250^{\circ} \mathrm{C}$ at a rate of $5{ }^{\circ} \mathrm{C} / \mathrm{min}$, and finally raised up to $310^{\circ} \mathrm{C}$ at a rate of $20^{\circ} \mathrm{C} / \mathrm{min}$. Identification of components were confirmed by comparison of the mass spectra with reference data from the National Institute Standard and Technology (NIST) library.

\section{RESULTS AND DISCUSSION}

In the present study, phytochemical investigation of different species belonging to the genus Albizia afforded different classes of secondary metabolites such as saponins, terpenes, alkaloids, and flavonoids [15]. Reports on other Albizia species showed that the methanolic extract of Albizia procera leaves possessed antioxidant activity (DPPH assay) with an $\mathrm{IC}_{50}$ of $43.43 \mu \mathrm{g} / \mathrm{ml}$ [16]. The ethanolic extract of Albizia myriophylla wood was reported for potential antioxidant and anti-inflammatory activities (both in vitro and in vivo). Using the DPPH, ABTS, and FRAP assays, it was demonstrated that the isolated compounds from the extract (indenoic acid and 8-methoxy-7,3,4 -trihydroxyflavone) had potent free radical scavenging effects [17]. The methanolic extract of $A$. adianthifolia leaves exhibited high content of phenolics (30.17 mg gallic acid/g) and high radical scavenging property (using DPPH assay) of 58.19\% [18].

The extraction yields of $A$. lucidior (Table 1 ) for the aqueous and the ethanolic extracts were 2.97 and $2.14 \%$, respectively. Mean total phenolic and flavonoid contents of the aqueous extract were $139.97 \pm 1.91 \mathrm{mg} \mathrm{GAE} / \mathrm{g}$ and $165.98 \pm 7.98 \mathrm{mg}$ $\mathrm{QE} / \mathrm{g}$; while those for the ethanolic extract were $116.19 \pm 1.22 \mathrm{mg} \mathrm{GAE} / \mathrm{g}$ and $221.62 \pm 9.69 \mathrm{mg}$ $\mathrm{QE} / \mathrm{g}$, respectively. The aqueous extract showed greater scavenger activity than the ethanolic extract in the ABTS and DPPH assay (Table 1). To the best of our knowledge, our research is the first publication on the antioxidant activity of A. lucidior wood extracts.

The determination of anti-inflammatory activities of the aqueous and ethanolic extracts of $A$. lucidior wood, by the NO and TNF- $\alpha$ assays revealed that only the ethanolic extract had anti-inflammatory activity, inhibiting $\mathrm{NO}$ production with an $\mathrm{IC}_{50}$ of $58.81 \mu \mathrm{g} / \mathrm{ml}$ (Table 1 and Fig. 1). Both extracts, at various concentrations, showed no cytotoxicity activity with viability percentage exceeding $70 \%$. 
Table 1 The percentage yield, total phenolic content, flavonoid content, antioxidant activities, and inhibition of NO and TNF- $\alpha$ productions of LPS-stimulated RAW 264.7 cells $(n=3)$ of $A$. lucidior wood extract by decoction and maceration methods!

\begin{tabular}{|c|c|c|c|c|c|c|c|}
\hline \multirow[t]{2}{*}{ Extract } & \multirow[t]{2}{*}{$\%$ Yield } & \multirow{2}{*}{$\begin{array}{c}\text { Total phenolic } \\
\text { content (mg GAE/g) }\end{array}$} & \multirow{2}{*}{$\begin{array}{c}\text { Total flavonoid } \\
\text { content (mg QE/g) }\end{array}$} & \multicolumn{4}{|c|}{$\mathrm{IC}_{50}(\mu \mathrm{g} / \mathrm{ml})$} \\
\hline & & & & DPPH assay & ABTS assay & Inhibition of NO & Inhibition of TNF- $\alpha$ \\
\hline Aqueous & 2.97 & $139.97 \pm 1.91$ & $165.98 \pm 7.98$ & $7.12 \pm 0.45$ & $9.50 \pm 1.22$ & $>100$ & $>100$ \\
\hline $95 \% \mathrm{EtOH}$ & 2.14 & $116.19 \pm 1.22$ & $221.62 \pm 9.69$ & $9.02 \pm 0.93$ & $27.44 \pm 1.20$ & $58.81 \pm 0.90$ & $>100$ \\
\hline BHT & - & - & - & $16.23 \pm 0.36$ & $5.21 \pm 0.56$ & - & - \\
\hline
\end{tabular}

${ }^{\dagger}$ RAW 264.7 cells were stimulated by $5 \mathrm{ng} / \mathrm{ml}$ of LPS. The concentrations of extracts were used to calculate IC $_{50}$ that displayed no cytotoxic (cell viability $>70 \%$ ).

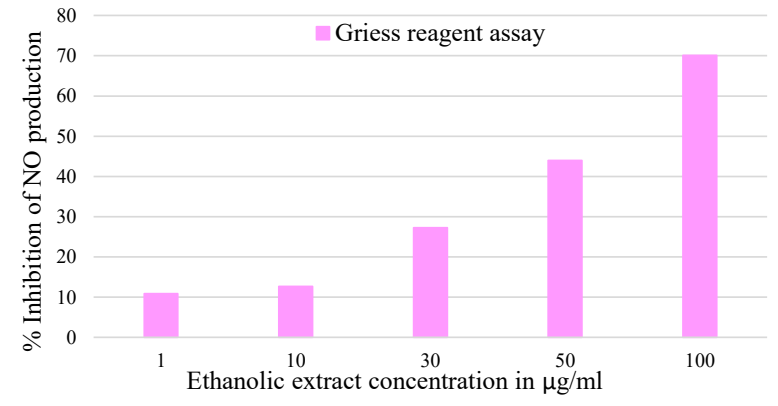

Fig. 1 The inhibition of nitric oxide production by different concentrations of the ethanolic extract of $A$. lucidior wood.

In consistent with a previous report, the ethanolic extract of A. myriophylla wood inhibited the release of nitric oxide production with $\mathrm{IC}_{50}$ value of $13.8 \mu \mathrm{g} / \mathrm{ml}$ [17]. In another study, methanolic extract from leaves of $A$. anthelmintica revealed antiinflammatory activity by decreasing the production of inflammatory mediators, PGE2 and leukotrienes, via inhibition of COX-1, COX-2, and 5-LOX, with $\mathrm{IC}_{50}$ values of $4.11,0.054$, and $1.74 \mu \mathrm{g} / \mathrm{ml}$, respectively [19]. Our findings suggest that the moderate in vitro anti-inflammatory activity of the ethanolic extracts may act mostly through the NO production pathway. However, further investigations for other mechanisms are needed.
In our experiments, only the ethanolic extract of A. lucidior wood inhibited Staphylococcus species with MICs values of $2.5-5 \mathrm{mg} / \mathrm{ml}$ (Table 2) in line with what reported by Duraipandiyan et al. At concentrations of $1.5,2.5$, and $5 \mathrm{mg}$ of methanolic extract of $A$. procera stem bark, there was dosedependent inhibition of $S$. aureus and $S$. epidermidis with inhibition zones of 9,11 , and $13 \mathrm{~mm}$, respectively [20]. On the other hand, the aqueous extract was less effective against all three pathogens. Antimicrobial susceptibility testing of different fractions of methanolic extract of $A$. procera leaves at a concentration of $800 \mu \mathrm{g} /$ disc inhibited $S$. aureus with inhibition diameter range of 7-12 $\mathrm{mm}$ [21]. Recently, the methanolic extract of $A$. adianthifolia roots and bark were reported to have antimicrobial activity against multi-drug resistant Gram-negative bacteria [22].

Based on the literature reviews and our results, the use of different extraction solvents yields different compounds with different properties, e.g., aqueous extracts contain phenolic compounds which possess greater antioxidant potential compared with organic extracts, whereas only ethanolic extracts contain active compounds with anti-inflammatory and anti-microbial activities.

The GC-MS analysis showed retention times of different chemical components (Fig. 2), and 39 compounds were identified being phenols, sterols,

Table 2 Antimicrobial activity of A. lucidior wood extracts and antibiotic drugs against $S$. aureus, MRSA, and S. epidermidis $(n=3)$.

\begin{tabular}{lccc}
\hline Treatment & \multicolumn{3}{c}{ MIC, MBC $^{*}$} \\
\cline { 2 - 4 } & S. aureus & MRSA & S. epidermidis \\
\hline Ethanolic extract $(\mathrm{mg} / \mathrm{ml})$ & $2.5,5$ & $2.5,>5$ & $5,>5$ \\
Aqueous extract $(\mathrm{mg} / \mathrm{ml})$ & $>5,>5$ & $>5,>5$ & $>5,>5$ \\
Ampicillin $(\mu \mathrm{g} / \mathrm{ml})$ & $7.8 \times 10^{-4},>100$ & $>100,-$ & $1.56,>100$ \\
Norfloxacin $(\mu \mathrm{g} / \mathrm{ml})$ & $1.56,>100$ & $7.8 \times 10^{-4},>100$ & $3.9 \times 10^{-4}, 1.56$ \\
\hline
\end{tabular}

\footnotetext{
$"=\mathrm{mg} / \mathrm{ml}$ for extracts and $\mu \mathrm{g} / \mathrm{ml}$ for antibiotic drugs.
} 


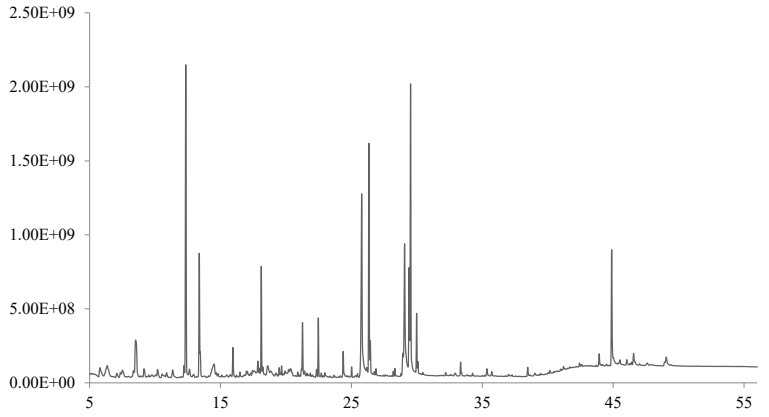

Fig. 2 GC-MS chromatogram of the ethanolic extract of A. lucidior wood.

and volatile oils. Likewise, different compounds were found from the phytochemical analysis of the ethanolic extract of the aerial parts of $A$. procera: carbohydrates and glycosides, phytosterols, triterpenoids, flavonoids, phenolic compounds, tannins, and saponin [23]. Table 3 shows the five highest peaks on the chromatogram of 2methoxy-3-(2-propenyl) (14.57\%), n-hexadecanoic acid (12.34\%), (E)-9-Octadecenoic acid ethyl ester (11.94\%), hexadecanoic acid, ethyl ester (8.94\%), and cis-vaccenic acid (8.88\%) as well as all the other compounds.

In a previous research, $n$-hexadecanoic acid was the main compound found in the A. amara leave extracts, and it was shown to have wound healing properties [24]. Using HPLC-PDA-ESI-MS analysis, mainly flavonoids and galloyl glucoside derivatives related to antioxidant and anti-inflammatory activities were found in the methanolic extract of $A$. anthelmintica leaves [19]. Thus, our study is a first report of wood of A. lucidior components analysis using GC-MS technique.

Table 3 Phytocomponents identified in the ethanolic extract of A. lucidior wood by GC-MS.

\begin{tabular}{|c|c|c|c|c|c|}
\hline NO. & $\mathrm{R} / \mathrm{T}^{\dagger}$ & Compound & Molecular formula & MW (g/mol) & Percentage \\
\hline 1 & 5.784 & 3-Acetylthymine & $\mathrm{C}_{7} \mathrm{H}_{8} \mathrm{~N}_{2} \mathrm{O}_{3}$ & 168 & 1.04 \\
\hline 2 & 8.518 & Tridecane & $\mathrm{C}_{13}^{8} \mathrm{H}_{28}^{2}$ & 184 & 0.34 \\
\hline 3 & 9.154 & 5-Hydroxymethylfurfural & $\mathrm{C}_{6} \mathrm{H}_{6}$ & 126 & 0.66 \\
\hline 4 & 10.182 & Massoilactone & $\mathrm{C}_{10}{ }_{0}^{6} \mathrm{H}$ & 168 & 0.64 \\
\hline 5 & 10.878 & Safrole & $\mathrm{C}_{10}^{10} \mathrm{H}_{10}^{16} \mathrm{O}_{2}^{2}$ & 162 & 0.39 \\
\hline 6 & 11.345 & 2-Methoxy-4-vinylphenol & & 150 & 0.69 \\
\hline 7 & 12.214 & Phenol, 2,6-dimethoxy- & $\mathrm{C}_{8}^{9} \mathrm{H}_{3}$ & 154 & 0.60 \\
\hline 8 & 12.345 & Phenol, 2-methoxy-3-(2-propenyl)- & $\mathrm{C}_{10}^{8} \mathrm{H}_{1}^{1}$ & 164 & 14.57 \\
\hline 9 & 13.377 & Heptadecane & $\mathrm{C}_{17} \mathrm{H}$ & 240 & 6.23 \\
\hline 10 & 13.449 & Vanillin & $\mathrm{C}_{8} \mathrm{H}_{8}$ & 152 & 0.39 \\
\hline 11 & 15.948 & 2H-Pyran-2-one, tetrahydro-4-hydroxy-6-pentyl- & $\mathrm{C}_{10}^{8} \mathrm{H}$ & 186 & 1.36 \\
\hline 12 & 17.851 & Butyrovanillone & $\mathrm{C}_{11}^{10} \mathrm{H}_{1}^{1}$ & 194 & 0.73 \\
\hline 13 & 17.956 & 2-Methyl-Z,Z-3,13-octadecadi & $\mathrm{C}_{19} \mathrm{H}_{3}$ & 280 & 0.31 \\
\hline 14 & 18.114 & Heptadecane & $\mathrm{C}_{17} \mathrm{H}$ & 240 & 4.02 \\
\hline 15 & 18.234 & 3-Heptafluorobutyroxytetrade & $\mathrm{C}_{18} \mathrm{H}_{29}$ & 410 & 0.20 \\
\hline 16 & 19.484 & Benzaldehyde, 4-hydroxy-3,5-dimethoxy- & & 182 & 0.34 \\
\hline 17 & 19.667 & aR-Turmerone & $\mathrm{C}_{15} \mathrm{H}_{20} \mathrm{O}$ & 216 & 0.38 \\
\hline 18 & 21.264 & (E)-4-(3-Hydroxyprop-1-en-1-yl)-2-methoxyphenol & $\mathrm{C}_{10}^{13} \mathrm{H}_{12}^{20} \mathrm{O}_{3}$ & 180 & 2.79 \\
\hline 19 & 22.335 & Oleic Acid & $\mathrm{C}_{18}^{10} \mathrm{H}_{34} \mathrm{O}_{2}^{3}$ & 282 & 0.32 \\
\hline 20 & 22.472 & Eicosane & $\mathrm{C}_{20} \mathrm{I}$ & 282 & 2.16 \\
\hline 21 & 24.373 & Lidocaine & $\mathrm{C}_{14} \mathrm{H}_{22} \mathrm{~N}_{2} \mathrm{O}$ & 234 & 1.09 \\
\hline 22 & 25.026 & Hexadecanoic acid, methyl ester & $\mathrm{C}_{17}^{14} \mathrm{H}_{34}^{22} \mathrm{O}_{2}$ & 270 & 0.36 \\
\hline 23 & 25.784 & n-Hexadecanoic acid & $\mathrm{C}_{16}^{1 /} \mathrm{H}_{32}^{34} \mathrm{O}_{2}^{2}$ & 256 & 12.34 \\
\hline 24 & 26.337 & Hexadecanoic acid, ethyl ester & $\mathrm{C}_{18}^{10} \mathrm{H}_{36}^{32} \mathrm{O}_{2}^{2}$ & 284 & 8.94 \\
\hline 25 & 26.446 & Tetracosane & $\mathrm{C}_{24} \mathrm{H}_{50}{ }^{2}$ & 338 & 1.33 \\
\hline 26 & 26.879 & Isopropyl palmitate & $\mathrm{C}_{19} \mathrm{H}_{38} \mathrm{O}_{2}$ & 298 & 0.25 \\
\hline 27 & 28.322 & 9-Octadecenoic acid (Z)-, methyl ester & $\mathrm{C}_{19}^{19} \mathrm{H}_{36}^{30} \mathrm{O}_{2}^{2}$ & 296 & 0.27 \\
\hline 28 & 28.932 & 9,12-Octadecadienoic acid $(\mathrm{Z}, \mathrm{Z})$ & $\mathrm{C}_{18}^{19} \mathrm{H}_{32}^{30} \mathrm{O}_{2}^{2}$ & 280 & 1.23 \\
\hline 29 & 29.064 & cis-Vaccenic acid & $\mathrm{C}_{18}^{10} \mathrm{H}_{34}^{32} \mathrm{O}_{2}^{2}$ & 282 & 8.88 \\
\hline 30 & 29.398 & 9(E),11(E)-Conjugated linoleic acid, ethyl ester & $\mathrm{C}_{20}^{10} \mathrm{H}_{36}^{34} \mathrm{O}_{2}^{2}$ & 308 & 4.51 \\
\hline 31 & 29.519 & (E)-9-Octadecenoic acid ethyl ester & $\mathrm{C}_{20}^{20} \mathrm{H}_{38}^{30} \mathrm{O}_{2}^{2}$ & 310 & 11.94 \\
\hline 32 & 29.988 & Octadecanoic acid, ethyl ester & $\mathrm{C}_{20}^{20} \mathrm{H}_{40}^{30} \mathrm{O}_{2}^{2}$ & 312 & 2.16 \\
\hline 33 & 30.079 & Hexacosane & $\mathrm{C}_{26} \mathrm{H}_{5}$ & 366 & 0.40 \\
\hline 34 & 33.346 & Eicosanoic acid, ethyl ester & $\mathrm{C}_{22} \mathrm{H}_{44} \mathrm{O}_{2}$ & 340 & 0.55 \\
\hline 35 & 35.358 & Benzyldiethyl-(2,6-xylylcarbamoylmethyl)-ammonium benzoate & $\mathrm{C}_{28} \mathrm{H}_{34} \mathrm{~N}_{2} \mathrm{O}_{3}$ & 446 & 0.40 \\
\hline 36 & 38.475 & (E)-3,3'-Dimethoxy-4,4'-dihydroxystilbene & $\mathrm{C}_{16} \mathrm{H}_{16} \mathrm{O}_{4}{ }^{3}$ & 272 & 0.39 \\
\hline 37 & 43.936 & Campesterol & $\mathrm{C}_{28} \mathrm{H}_{48} \mathrm{O}^{4}$ & 400 & 0.50 \\
\hline 38 & 44.890 & beta.-Sitosterol & $\mathrm{C}_{29}^{28} \mathrm{H}_{50}^{48} \mathrm{O}$ & 882 & 5.64 \\
\hline 39 & 49.553 & Cholest-4-en-3-one & $\mathrm{C}_{27} \mathrm{H}_{44} \mathrm{O}$ & 384 & 0.66 \\
\hline
\end{tabular}

\footnotetext{
${ }^{\dagger} \mathrm{R} / \mathrm{T}=$ retention time.
} 


\section{CONCLUSION}

The wood of $A$. lucidior is commonly used as a traditional treatment for various ailments such as fever and general fatigue. Our study has shown that the ethanolic extract of $A$. lucidior exerted significant anti-free-radical activity and moderate inhibition of NO production, but anti-Staphylococcal activity was poor. These encouraging results support the use of A. lucidior in traditional medicine for the treatment of non-specific fever. The extracts should be further investigated to see if they may have a clinical application outside of the traditional medicine.

Acknowledgements: This study was supported by Thammasat University Research Fund, Contract No. TUFT $057 / 2563$. The authors are grateful to faculty of Medicine, Thammasat University for providing logistic support and encouragement to carry out this research. Also, we thank Dr. Bob Taylor for reviewing the manuscript.

\section{REFERENCES}

1. Walter EJ, Hanna-Jumma S, Carraretto M, Forni L (2016) The pathophysiological basis and consequences of fever. Crit Care 20, ID 200.

2. Kany S, Vollrath JT, Relja B (2019) Cytokines in inflammatory disease. Int J Mol Sci 20, ID 6008.

3. Slater D, Kunnathil S, McBride J, Koppala R (2010) Pharmacology of nonsteroidal antiinflammatory drugs and opioids. Semin Intervent Radiol 27, $400-411$.

4. Lourenco SC, Moldao-Martins M, Alves VD (2019) Antioxidants of natural plant origins: From sources to food industry applications. Molecules 24, ID 4132.

5. Lobo V, Patil A, Phatak A, Chandra N (2010) Free radicals, antioxidants, and functional foods: Impact on human health. Pharmacogn Rev 4, 118-126.

6. Dechayont B, Phuaklee P, Chunthorng-Orn J, Poomirat S, Prajuabjinda O, Vilaichone R, Itharat A (2019) Anti-Helicobacter pylori, anti-inflammatory and antioxidant evaluation of crude extracts from Amomum krervanh fruits. ScienceAsia 45, 109-115.

7. Dechayont B, Sukkan B, Sakpakdeejareon I, Itharat A (2010) Study on cytotoxic and antioxidant activities of Pseuderathemum platiferum. Thai J Pharmacol 32, 50-53.

8. Dechayont B, Ruamdee P, Poonnaimuang S, Mokmued K, Chunthorng-Orn J (2017) Antioxidant and antimicrobial activities of Pogostemon cablin (Blanco) Benth. $J$ Bot 2017, ID 8310275.

9. Dechayont B, Itharat A, Phuaklee P, ChunthorngOrn J, Juckmeta T, Prommee N, Nuengchamnong N, Hansakul P (2017) Antioxidant activities and phytochemical constituents of Antidesma thwaitesianum Mull. Arg. leaf extracts. J Integr Med 15, 310-319.
10. Re R, Pellegrini N, Proteggente A, Pannala A, Yang M, Rice-Evans C (1999) Antioxidant activity applying an improved ABTS radical cation decolorization assay. Free Radic Biol Med 26, 1231-1237.

11. Suthisamphat N, Dechayont B, Phuaklee P, Prajuabjinda O, Vilaichone RK, Itharat A, Mokmued K, Prommee N (2020) Anti-Helicobacter pylori, antiinflammatory, cytotoxic, and antioxidant activities of mace extracts from Myristica fragrans. Evid Based Complement Alternat Med 2020, ID 7576818.

12. Dechayont B, Phuaklee P, Chunthorng-Orn J, Poomirat S, Juckmeta T, Phumlek K, Mokmued K, Ouncharoen K (2020) Antimicrobial, anti-inflammatory, and antioxidant activities of the wood of Myristica fragrans Houtt. J Herbs Spices Med Plants 26, 49-60.

13. Sarker SD, Nahar L, Kumarasamy Y (2007) Microtitre plate-based antibacterial assay incorporating resazurin as an indicator of cell growth, and its application in the in vitro antibacterial screening of phytochemicals. Methods 42, 321-324.

14. McNicholl BP, McGrath JW, Quinn JP (2007) Development and application of a resazurin-based biomass activity test for activated sludge plant management. Water Res 41, 127-133.

15. Asgarirad H, Chabra A, Rahimnejad M, Hosseinzadeh AZ, Davoodi A, Azadbakht M (2018) Comparison of Albizia julibressin and silver sulfadiazine in healing of second-and third-degree burns. World J Plast Surg 7, 34-44.

16. Khatoon M, Islam E, Islam R, Rahman AA, Alam AK, Khondkar P, Rashid M, Parvin S (2013) Estimation of total phenol and in vitro antioxidant activity of Albizia procera leaves. BMC Res Notes 6, ID 121.

17. Bakasatae N, Kunworarath N, Yupanqui CT, Voravuthikunchai SP, Joycharat N (2018) Bioactive components, antioxidant, and anti-inflammatory activities of the wood of Albizia myriophylla. Rev Bras Farmacogn 28, 444-450.

18. Beppe GJ, Dongmo AB, Foyet HS, Tsabang N, Olteanu Z, Cioanca O, Hancianu M, Dimo T, et al (2014) Memory-enhancing activities of the aqueous extract of Albizia adianthifolia leaves in the 6-hydroxydopamine-lesion rodent model of Parkinson's disease. BMC Complement Altern Med 14, 142.

19. Sobeh M, Rezq S, Sabry OM, Abdelfattah MAO, El Raey MA, El-Kashak WA, El-Shazly AM, Mahmoud MF, et al (2019) Albizia anthelmintica: HPLC-MS/MS profiling and in vivo anti-inflammatory, pain killing and antipyretic activities of its leaf extract. Biomed Pharmacother 115, ID 108882.

20. Duraipandiyan V, Ayyanar M, Ignacimuthu S (2006) Antimicrobial activity of some ethnomedicinal plants used by Paliyar tribe from Tamil Nadu, India. BMC Complement Altern Med 6, ID 35.

21. Khatoon MM, Khatun MH, Islam ME, Parvin MS (2014) Analgesic, antibacterial and central nervous system depressant activities of Albizia procera leaves. 
Asian Pac J Trop Biomed 4, 279-284.

22. Tchinda CF, Voukeng IK, Beng VP, Kuete V (2017) Antibacterial activities of the methanol extracts of $\mathrm{Al}$ bizia adianthifolia, Alchornea laxiflora, Laportea ovalifolia and three other Cameroonian plants against multi-drug resistant Gram-negative bacteria. Saudi $J$ Biol Sci 24, 950-955.
23. Sivakrishnan S, KottaiMuthu A (2014) Phytochemical evaluation of ethanolic extract of aerial parts of Albizia procera. Br Med Bull 1, 235-241.

24. Devi DR, Lakshna SS, Parvathi SV, Vedha Hari BN (2018) Investigation of wound healing effect of topical gel of Albizia amara leaves extract. $S$ Afr J Bot 119, 400-409. 